UDC 576.533

\title{
Proliferation of Wharton jelly mesenchymal stem cells, derived by preserving the cells with reduced attachment rate, under various gas conditions
}

\author{
N. S. Shuvalova ${ }^{1}$, V. A. Kordium ${ }^{1,2}$ \\ ${ }^{1}$ State Institute of Genetic and Regenerative Medicine, NAMS of Ukraine \\ 67, Vyshhorodska Str., Kyiv, Ukraine, 04114 \\ ${ }^{2}$ Institute of Molecular Biology and Genetics, NAS of Ukraine \\ 150, Akademika Zabolotnoho Str., Kyiv, Ukraine, 03680 \\ riyena@yandex.ua
}

\begin{abstract}
Aim. To estimate the proliferation rates in cultures of the human Wharton jelly mesenchymal stem cells (WJ-MSCs), obtained by the method of preservation of spontaneously detached cells, in various gas mixtures, containing physiological oxygen concentrations. Methods. Starting from the first passage, WJ-MSC were cultured for 4 subsequent passages, 7 days between replating ("main" line"). At 0,1 and 2 passage, day 3 of cultivation, conditioned media was collected and transferred to another flack with complete growth media. The attached cells from conditioned media were cultivated until the clones size and confluence (70-80\%) became sufficient for replating, and after that were subsequently passed with trypsin-EDTA solution ("side" lines). Besides the cultivation in standard condition of $\mathrm{CO}_{2}$-incubator, the cultivation was conducted in the nitrogen-based gas mixture (3\% oxygen, $4 \%$ carbon dioxide, $93 \%$ nitrogen) and argonbased gas mixture (3\% oxygen, $4 \%$ carbon dioxide, $93 \%$ argon). At each passage, the number of cells was counted. Results. The proliferation level in "side" lines, obtained from 0 and 1 passages, had a lot of similarities with that of "main" line. We observed the trend of multiplication rate reduction in "side" lines during in vitro maintenance, similar to that in "main" line. For cultures, obtained at the passage 2, the level of proliferation was significantly lower. The cultivation in both gas mixtures with $3 \% \mathrm{O}_{2}$ concentration had beneficial effect on the level of cell multiplication: the number of cells was significantly higher. The effect of argon-based mixture was more pronounced. Conclusion. The physiologic oxygen tension allows optimizing the cultivation of WJ-MSC, obtained by the suggested method of preserving the cells with reduced attachment ability.
\end{abstract}

Ke y w o r d s: mesenchymal stem cells, proliferation, subpopulation, physiological oxygen concentrations

\section{Introduction}

At present, mesenchymal stem cells (MSC) are considered as a promising tool for the cell therapy. Among MSC from different sources, MSC from Wharton jelly umbilical cord matrix (WJ-MSC) are considered to be especially perspective because of their high differentiation potential [1], paracrine [2] and immune [3] effects.
In the organism, the MSC natural location site, "niche", plays a major role in the preservation of their main features. Besides MSC, the niche includes the neighboring cells producing the signal molecules, and an extracellular matrix. One of the key factors regulating the niche's behavior is the oxygen concentration, which is lower, than in other sites of the tissue [4].

\footnotetext{
(C) 2015 N. S. Shuvalova et al.; Published by the Institute of Molecular Biology and Genetics, NAS of Ukraine on behalf of Biopolymers and Cell. This is an Open Access article distributed under the terms of the Creative Commons Attribution License (http://creativecommons.org/licenses/by/4.0/), which permits unrestricted reuse, distribution, and reproduction in any medium, provided the original work is properly cited
} 
For clinical practice, the ex vivo multiplication of MSC is inevitable. The cultivation process is associated with the risk of losing clinically relevant features, accumulation of genetic abnormalities and possible malignization, because in vitro the cells are forced to adapt to the conditions, that drastically differ from those of their natural location [5]. $\mathrm{O}_{2}$ concentration in the standard conditions of a $\mathrm{CO}_{2}-$ incubator is nearly equal to the atmospheric one, thus, being "hyperoxic" for MSC, leading to the progressing accumulation of the oxidative damage [6]. Besides, generally accepted use of the proteolytic enzymes solutions and mechanical manipulations during a passing procedure leads to the damage of homing receptors and adhesion molecules on the cell surface, having a negative impact on the regenerative potential of cultured MSC [7-9]. Thus, the development of methods to minimize the damages, accompanying the cultivation process, is considered an important task. Numerous works showed, that MSC cultivation in the gas mixtures containing oxygen of concentrations similar to the physiological ones, is beneficial for the activation of growth and reducing the oxidative stress. Another perspective approach is the development of methods to avoid the procedure of detaching cells from a substrate, for instance, cultivation in $3 \mathrm{D}$ constructs or on various carriers [10], that is often technically complicated.

In our previous work we have suggested the method of optimization of human WJ-MSC cultivation. It allowed preservation and multiplication of the cells, that spontaneously detached during cultivation (presumably, in the phase prior to mitosis), thus obtaining the populations of MSC, that avoided the damaging influence of a passing procedure on the surface molecules [11]. Besides, we have shown a positive effect of the nitrogen- and argon-based cultivation gas mixtures containing $3 \% \mathrm{O}_{2}$ [12]. The aim of the present study was to evaluate the cell proliferation in human WJ-MSC cultures, obtained by the suggested method, termed "self-replating", in various gas mixtures, containing oxygen in physiological concentrations.

\section{Materials and Methods}

\section{MSC isolation}

MSC were obtained from human Wharton jelly using the explant method [13]. Umbilical cords (UC) were collected from three healthy donors (39-40 weeks of gestation, normal delivery).

The UC fragment $(5-10 \mathrm{~cm})$ was washed with PBS, the vessels were mechanically removed. WJ was mechanically cut, the pieces were placed in the cultural flacks, $75 \mathrm{~cm}^{2}$, containing complete growth medium (DMEM with low glucose (PAA, Austria) supplemented with $10 \%$ fetal bovine serum (PAA, Austria), glutamine $2 \mathrm{mM}$ (PAA,Austria), penicillin $100 \mathrm{U} / \mathrm{ml}$ (Arterium, Ukraine), streptomycin $100 \mu \mathrm{g} / \mathrm{ml}$ (Arterium, Ukraine). The first attached cells were visible on the $7-10^{\text {th }}$ day. After 14 days the clones reached the size and confluence (70-80\%) sufficient for passing.

At the first passage the surface marker proteins CD90, CD73, CD105 expression was estimated (over $85 \%$ positive), using flow cytometry (BD FACS Aria) with fluorescein- and rhodamine-conjugated antibodies (UsBiological, USA).

\section{Proliferation analysis, standard passing}

Starting from the passage $1(\mathrm{P} 1)$, WJ-MSC were plated on the flacks of $25 \mathrm{~cm}^{2}, 75 \cdot 10^{3}$ cells per flack, and cultured for 4 subsequent passages (for 7 days at each passage).These cultures were further referred to as a "main" line. The cells were passed using trypsin-EDTA (0.1\% trypsin and $0.02 \%$ EDTA) solution (TE-passing). At each passage, a final number of cells was estimated by counting in hemocytometer (Goryaev chamber).

\section{"Self-replating" culture obtaining and proliferation analysis}

At passages $0-2$ ( $\mathrm{P} 0-\mathrm{P} 2)$, on the day 3 of cultivation, the conditioned media ( $6 \mathrm{ml}$ from each flack) was gathered, centrifuged and transferred to another flack with the complete growth media (described above). After the first attached cells were visible (day 2-5 after media transfer), the cultures were cultivated for nearly 1.5 weeks until the clones size and 
confluence (70-80\%) became sufficient for replating ( Fig. 1 - passages marked as 0a, 1a, 2a). After the first replating, the cells were seeded on the flack of $25 \mathrm{~cm}^{2}, 75 \cdot 10^{3}$ cells per flack, and subsequently passed using TE solution. During each replating, the cells were counted in hemocytometer (Goryaev chamber).

\section{WJ-MSC cultivation in gas mixtures}

The flacks with WJ-MSC cultures were placed into the polyethylene bags with hermetic clasp (1.5 1). The bags were washed twice with the gas mixture, containing $4 \% \mathrm{CO}_{2}$ and $96 \%$ of nitrogen or argon (depending on the group), after that were filled with the gas mixture used for cultivation (see below), and set in the vacuum containers (Scarlet). The containers with bags were kept at $37^{\circ} \mathrm{C}$, gas mixture was substituted in 3 days. The experimental groups were cultured in the gas mixtures based on nitrogen (oxygen $-3 \%, \mathrm{CO}_{2}-4 \%$, nitrogen $-93 \%$ ) and argon (oxygen $-3 \%, \mathrm{CO}_{2}-4 \%$, argon $-93 \%$ ). The control group was maintained in the $\mathrm{CO}_{2}$ incubator (ambient oxygen concentration $-20 \%, \mathrm{CO}_{2}-4 \%$ )

\section{Microscopy}

Microscopy was performed with an inverted microscope Leica DMIL. Images were taken by camera Cannon PowerShot 640A, x100, zoom x1,4.

\section{Statistics}

The data on cell numbers are reported as mean \pm standard deviation for three samples. Statistical significance was determined using Mann-Whitney U-test at $\mathrm{P}<0.05$.

\section{Results}

\section{WJ-MSC isolation, primary culture} and "self-replating" method

On the $7-10^{\text {th }}$ day after the WJ fragments were put into the cultural flacks, the first attached cells were visible, both single and in groups of 4-10. The clones reached the number of cells and confluence (70$80 \%$ ) sufficient for passing after 10-14 days, and were replated using trypsin-EDTA $(0.1 \%$ trypsin and $0.02 \%$ EDTA) solution (TE-passing). The surface marker proteins analysis was performed at the first passage and showed that over $85 \%$ of population are positive for CD73, CD90, and CD105. The line was passed subsequently for 4 passages.

At passage 0 , passage 1 and passage 2 ( $\mathrm{P} 0, \mathrm{P} 1$ and $\mathrm{P} 2)$, on $3-4^{\text {th }}$ day after the cells were seeded, the conditioned media were collected and transferred to a new flack (as described in Materials and Methods). In 2-5 days the first attached cells (single or clones of $2-6$ cells) were visible. The obtained cells proliferated and thus started a new "side" line (see further).

\section{Growth analysis of obtained "self-replating" cultures}

It is known, that during the phase of cell cycle prior to the division, as well as during the mitosis, the level of cell adhesion to a substrate decreases [14]. The method allowing preservation of the cells, that spontaneously detached, or, in other words, "selfreplating" (in present work this terms are used as synonyms) is based on the fact, that the MSC culture is usually asynchronous. In the flacks containing the conditioned media from MSC cultures, the attached cells, able to form clones, can be viewed already in 2-5 days. The morphological and surface markers of the cells obtained by this method resembled those of the original culture, confirming that "self-replated" cells descend from the cells, the adhesion of which to a substrate reduced before or during the division [11].

The method of "self-replating" can be used for the additional obtaining of MSC cultures, as well as for the estimation of the clonogenic ability of the entire population at current time point. It can be used as additional to widely used methods of proliferation analysis, showing the number of dividing cells, their ability to form viable colonies, and, indirectly, the peculiarities of their adhesion to substrate.

Fig 1. illustrates the scheme of media collecting and obtaining "self-replating" cultures.

It is important to compare the measured parameters in standardized conditions for both TE-passed WJ-MSC and ones of "self-replating" origin. The 


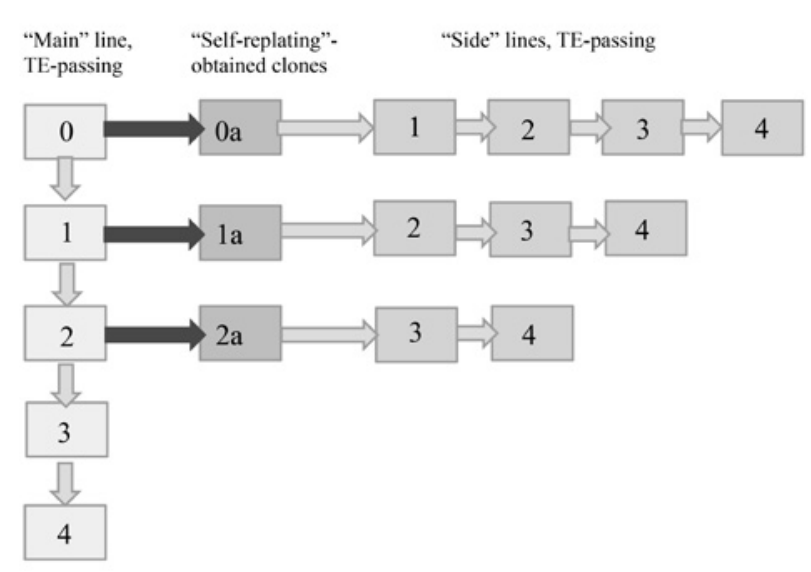

Fig. 1. Obtaining cultures by "self-replating" method, and their subsequent TE-passing . Blocks - cultures, numbers - the numbers of passage. Light arrows - standard passing (TE), dark arrows - "self-replating" method.

estimated parameter to compare was the final number of cells after the standardized time of maintenance at each passage. For this aim, it was important to standardize the initial number of seeded cells, and the time between replatings -7 days.

The WJ-MSC cultures, passed using only TEsolution from $\mathrm{P} 0$, were contingently termed as the "main" line. At passages 0, 1 and 2 of TE-passed "main" line, the conditioned media were collected, and, using the "self-replating" method, the clones were obtained. After these clones reached the sufficient confluence, they were passed using TE solution for several subsequent passages, thus starting the "side" lines, termed 0a, 1a, 2a (Fig. 1). The term reflects the passage number, from which the media were gathered. This TE-replating was a necessary condition for the abovementioned standardization of the initial number of cells and time of their maintenance at each passage.
On the scheme in Fig. 1 the "self-replating"-obtained clones are marked as $0 \mathrm{a}, 1 \mathrm{a}$ and $2 \mathrm{a}$. Since there was a question, whether the clones, obtained from the conditioned media, are separate passages we was decided to compare the cultures that went through the equal numbers of TE-passings from the stage of primary culture, obtained directly from WJ fragments .

Fig. 1 illustrates this. The general number of light arrows shows the number of TE-passings. For example, WJ-MSC from "side" line $2 \mathrm{a}$ went through two TE-passings in "main" line, and two TE-passings after "self-replating" stage, which makes 4 full TE-passings.

The number of cells after 7 days of cultivation, at different passages, is summarized in Table 1.

The data showed, that proliferation of cells in "side" lines had the same trends as in "main" line. The level of multiplication of WJ-MSC after each next passage reduced in all groups, regardless the number of "parent" passage of "main" line.

Nevertheless, several differences were revealed. The trend of proliferative activity reduction in "side" lines, obtained from P0 and P1, in general, was very close to that in "main", only TE-passed line. But for the cultures, obtained from P2, the level of proliferation was significantly lower, than in "main" line (Table 1).

For example, at P3, though both "main" and "side" lines were passed with TE-solution for 3 times, the number of cells was significantly different. For "main" line and "side" line 0a and 1a, these numbers were very close $\left(317.53 \pm 25.23 \cdot 10^{3}\right.$, $338.56 \pm 11.36 \cdot 10^{3}$ and $317.57 \pm 4.41 \cdot 10^{3}$ of cells, respectively), but 2 a line showed significantly lower number $-252.32 \pm 15.73 \cdot 10^{3}$ cells (see Table 1 ).

Table 1. Comparison of cell number in MSC cultures at each passage, 7 days after replating, in "main" and "side" lines

\begin{tabular}{|l|c|c|c|c|}
\hline $\begin{array}{c}\text { TE- } \\
\text { passage }\end{array}$ & "Main" line, $10^{3}$ & "Side line $0 \mathrm{a}, 10^{3}$ & "Side line 1a,10 & "Side line $2 \mathrm{a}, 10^{3}$ \\
\hline 1 & $471.72 \pm 9.69$ & $462.64 \pm 4.27$ & & \\
2 & $444.58 \pm 19.07$ & $466.02 \pm 8.49$ & $457.63 \pm 9.35$ & $252.32 \pm 15.73$ \\
3 & $317.53 \pm 25.23$ & $338.56 \pm 11.36$ & $317.57 \pm 4.41$ & $132.36 \pm 14.01$ \\
4 & $233.63 \pm 5.10$ & $239.9 \pm 16.74$ & $232.96 \pm 11.08$ & \\
\hline
\end{tabular}



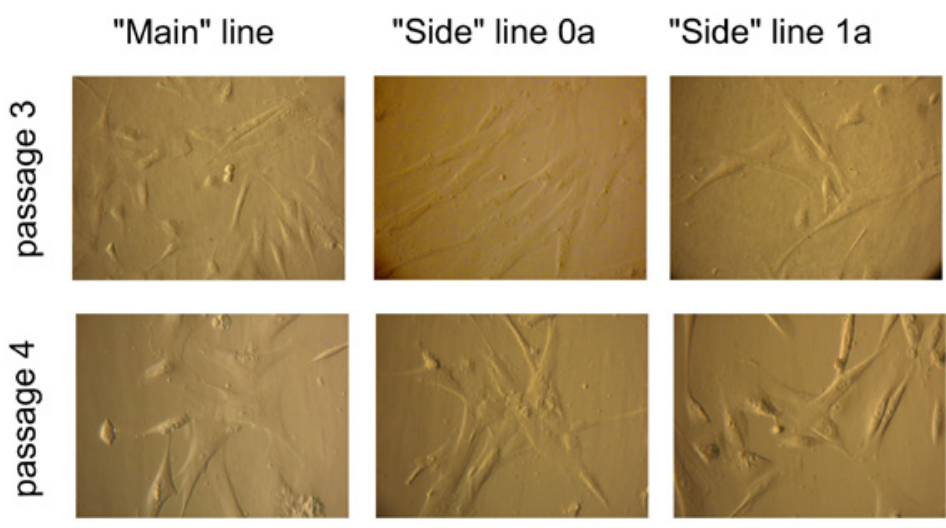

"Side" line 2a
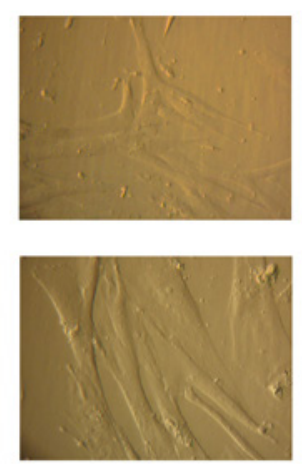

Fig. 2. Microphotography of cultures at passage 3 and passage 4, "main" and 0a,1a and $2 \mathrm{a}$ " side" lines (x100, camera zoom 1,4).

\section{Morphology}

The microphotographs of cultures of "main" and "side" lines at P3 and P4 are shown in Fig. 2.

MSC normally exhibit the fibroblast-like morphology. A spindle-like shape is considered to be typical for them.

During the cultivation period, the morphology of WJMSC cultures changed in all groups. At P3, and, especially, P4 the cells of flattened shape appeared. In literature, such phenotype is considered to be typical for the senescent cells $[15,16]$. Notably, the cultures of "main", $0 \mathrm{a}$ and 1a "side" lines contained similar number of such cells. At the same time, the number of cells with senescent phenotype in 2a line, was visibly higher (Fig. 2.)

\section{Proliferation of cells in cultures under physiological oxygen tensions}

In present study, the analysis of WJ-MSC proliferation of "main" and "side" lines was also conducted under conditions of mild hypoxia. WJ-MSCs were cultured in various gas mixtures - based on nitrogen (oxygen $-3 \%, \mathrm{CO}_{2}-4 \%$, nitrogen $-93 \%$ ) and argon (oxygen $-3 \%, \mathrm{CO}_{2}-4 \%$, argon $-93 \%$ ).

Fig 3, 4 and 5 show the comparison of cell number in cultures after 7 days of the cultivation.

The cultivation in both gas mixtures with $3 \% \mathrm{O}_{2}$ had beneficial effect on the level of cell multiplication: the number of cells was significantly higher. For example, at $\mathrm{P} 3$, the number of cells in "side" line $0 \mathrm{a}$ was $438.69 \pm 10.88 \cdot 10^{3}$ in nitrogen-based gas mixture and $426.73 \pm 12.09 \cdot 10^{3}$ in argon-based gas mixture comparing to $338.56 \pm 11.36 \cdot 10^{3}$ in $\mathrm{CO}_{2}$ incubator; “ side" line $1 \mathrm{a}-425.3 \pm 7.42 \cdot 10^{3}$ in nitrogen-based gas mixture and $425.24 \pm 9.59 \cdot 10^{3}$ in argon-based gas mixture comparing to $317.57 \pm 4.41 \cdot 10^{3}$ in $\mathrm{CO}_{2}$ incubator; "side" line $2 \mathrm{a}-354.07 \pm 13.25 \cdot 10^{3}$ in nitrogenbased gas mixture and $365.14 \pm 17.63 \cdot 10^{3}$ in argonbased gas mixture comparing to $252.33 \pm 15.73 \times 10^{3}$.

Interestingly, the beneficial effect appeared to be more pronounced in the argon-based gas mixture, comparing to the nitrogen-based gas mixture and standard conditions of $\mathrm{CO}_{2}$-incubator, for the most groups of the cultures obtained by "self-replating". For instance, for line 1a, the number of cells cultivated in the argon-based gas mixture was $323.35 \pm$ $12.12 \cdot 10^{3}$ whereas in the nitrogen-based gas mixture it reached $310.61 \pm 6.05 \cdot 10^{3}$ and $232.96 \pm 11.08 \cdot 10^{3}$ in the $\mathrm{CO}_{2}$ incubator conditions.

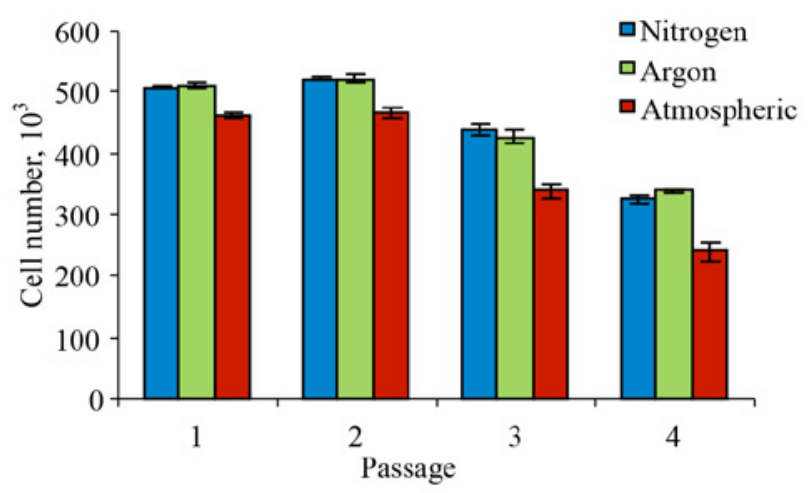

Fig. 3. Comparison of MSC number in MSC cultures in 0a line, at each passage, after 7 days of cultivation. "nitrogen" - nitrogenbased gas mixture (oxygen $-3 \%, \mathrm{CO}_{2}-4 \%$, nitrogen $93 \%$ ), "argon" - argon-based gas mixture (oxygen $-3 \%, \mathrm{CO}_{2}-$ $4 \%$, argon-93\%), "atmospheric" - conditions of $\mathrm{CO}_{2}$ incubator. 


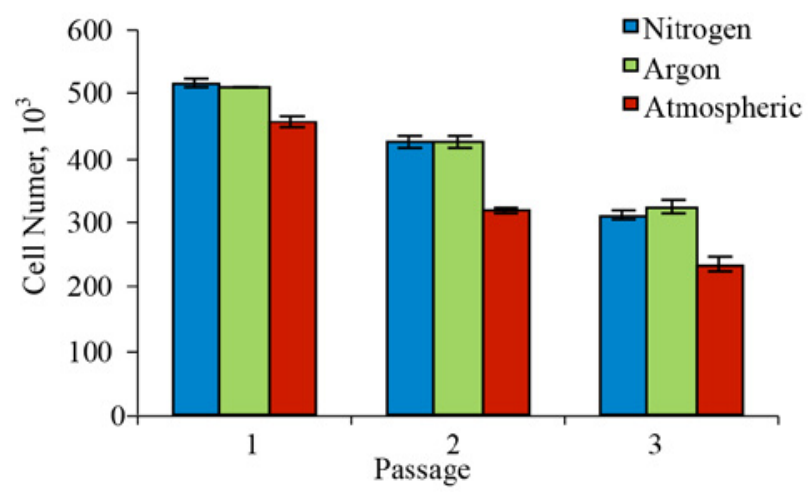

Fig. 4. Comparison of MSC number in MSC cultures in 1a line, at each passage, after 7 days of cultivation. "nitrogen" - nitrogenbased gas mixture (oxygen $-3 \%, \mathrm{CO}_{2}-4 \%$, nitrogen - $93 \%$ ), , argon" - argon-based gas mixture (oxygen - $3 \%, \mathrm{CO}_{2}-4 \%$, argon $-93 \%$ ), "atmospheric" - conditions of $\mathrm{CO}_{2}$ incubator.

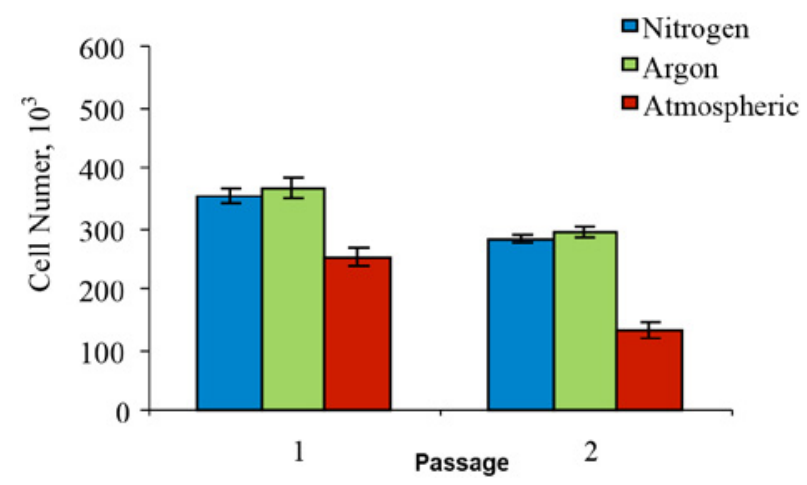

Fig. 5. Comparison of MSC number in MSC cultures in 2a line, at each passage, after 7 days of cultivation. "nitrogen" - nitrogen-based gas mixture (oxygen $-3 \%, \mathrm{CO}_{2}-4 \%$, nitrogen $93 \%$ ), "argon" - argon-based gas mixture (oxygen - $3 \%, \mathrm{CO}_{2}-$ $4 \%$, argon $-93 \%$ ), "atmospheric" - of $\mathrm{CO}_{2}$ incubator.

Importantly, in fact, the cultivation period is longer for the side lines, because of "additional" time needed for the growth of "self-replated" clones. On the average, it took about 12 days for clones to reach the number and confluence sufficient for passing. It is possible, that this "delay" influenced the revealed difference between the effect of gas mixtures on the multiplication in "main" and "side" lines.

\section{Discussion}

The proliferation rate is an important criterion of estimation of the state of culture, and in vitro mul- tiplication itself is a crucial stage for practical use. It is highly dependent on the cultivation conditions, each parameter having special mechanisms of influence.

The analysis of growth of the culture, obtained by the "self-replating" method, can be used to evaluate the entire population's number of dividing cells and their viability. Interestingly, in comparison with the culture, passed standardly, using proteolytic enzyme solutions, the culture obtained by "self-replating" is maintained in vitro for a longer period of time. Such extension of the general cultivation period occurs because of "delay" at the stage of growth of "selfreplating"-derived clones.

According to current literature, the cell in adhesive culture, in the phase prior to mitotic division, acquires a round shape, and the level of its adhesion to substrate reduces [17-19]. Hence, because of mechanical impact during cultural media substitution, the actively proliferating cells become easy to detach. In this case, "self-replated" culture can appear to be a special subpopulation. The difference in growth of TE-passed and "self-replating"-derived WJ-MSC, to some extent, confirms the possibility of this variant.

The present study also revealed an interesting fact of a noticeable decline in the proliferation rates starting at the passage 2 for both TE-passed cultures, and in "side" lines, obtained from the media collected at P2 of "main" culture. This can give a clue to the understanding of certain degradation processes in culture, P2 being a "threshold" one.

In this work we also estimated the proliferation levels, rates in WJ-MSC cultures, maintained under $3 \%$ oxygen, in gas mixtures based on nitrogen and argon. For TE-passed cultures, the highest levels of proliferation can be observed in the cultures, maintained in nitrogen-based mixtures [12]. At the same time, estimation of proliferation rates in cultures, "self-replating"-obtained from P0-P2, and subsequently passed using standard method, showed a more pronounced positive effect of argon-based mixture. Only several works describe the influence of inert gases (xenon and argon) on cell cultures, 
mostly of neural origin [20, 21]. The modern literature lacks the data about the inert gases influence on MSC. The present work showed that effect of argon can be revealed during long terms of cultivation.

\section{Conclusions}

Proliferation characteristics of WJ-MSC cultures, obtained by "self-replating" method at passage 0 and passage 1 , resemble those of cultures, passed by generally accepted method (using trypsin-EDTA solution). The cultures, "self-replating"- obtained at passage 2 had a lower, though sufficient, level of multiplication.

Morphology of the cultures, obtained by "self-replating" method from $\mathrm{P} 0$ and $\mathrm{P} 1$ was practically identical to that of "main", trypsin-EDTA solution -passed line. At the same time, the "side" line from P2 contained more cells with the senescent phenotype.

Gas mixtures with $3 \% \mathrm{O}_{2}$ had beneficial effect for the MSC proliferation potential. For the cultures, obtained by "self-replating", the stimulating effect of argon was more pronounced.

The suggested method allows preventing the loss of actively proliferative cells during culture maintenance, and obtaining the additional population of WJ-MSC, that avoided an impact of proteolytic enzymes on surface, during the whole period of in vitro maintenance. We also showed that using the cultivation under physiologic oxygen tension allows optimization of the method, preserving the proliferative potential of obtained cultures.

\section{REFERENCES}

1. Taghizadeh RR, Cetrulo KJ, Cetrulo CL. Wharton's Jelly stem cells: future clinical applications. Placenta. 2011;32 Suppl 4:S311-5.

2. Hsieh JY, Wang HW, Chang SJ, Liao KH, Lee IH, Lin WS, $W u$ CH, Lin WY, Cheng SM. Mesenchymal stem cells from human umbilical cord express preferentially secreted factors related to neuroprotection, neurogenesis, and angiogenesis. PLoS One. 2013;8(8):e72604.

3. Le Blanc $K$. Immunomodulatory effects of fetal and adult mesenchymal stem cells. Cytotherapy. 2003;5(6):485-9.

4. Watt FM, Hogan BL. Out of Eden: stem cells and their niches. Science. 2000;287(5457):1427-30.
5. Rubio D, Garcia-Castro J, Martín MC, de la Fuente R, Cigudosa JC, Lloyd AC, Bernad A. Spontaneous human adult stem cell transformation. Cancer Res. 2005;65(8):3035-9.

6. Basciano L, Nemos C, Foliguet B, de Isla $N$, de Carvalho $M$, Tran N, Dalloul A. Long term culture of mesenchymal stem cells in hypoxia promotes a genetic program maintaining their undifferentiated and multipotent status. BMC Cell Biol. 2011;12:12.

7. Rombouts WJ, Ploemacher RE. Primary murine MSC show highly efficient homing to the bone marrow but lose homing ability following culture. Leukemia. 2003;17(1):160-70.

8. Reilly $G C$, Engler $A J$. Intrinsic extracellular matrix properties regulate stem cell differentiation. J Biomech. 2010;43(1):55-62.

9. Angelucci S, Marchisio M, Di Giuseppe F, Pierdomenico L, Sulpizio M, Eleuterio E, Lanuti P, Sabatino G, Miscia S, Di Ilio $C$. Proteome analysis of human Wharton's jelly cells during in vitro expansion. Proteome Sci. 2010;8:18.

10. Witte H, Stubenrauch M, Fröber U, Fischer R, Voges D, Hoffmann $M$. Integration of 3-D cell cultures in fluidic microsystems for biological screenings. Eng Life Sci. 2011;(11):140-7.

11. Shuvalova NS, Maslova OA, Sukhorada OM, Deryabina $O G$, Kordium VA. Maintenance of mesenchymal stem cells culture due to the cells with reduced attachment rate. Biopolym Cell. 2013; 29(1):75-8.

12. Shuvalova NS, Kordium VA. Comparison of proliferative activity of Wharton jelly mesenchymal stem cells in cultures under various gas conditions. Biopolym Cell. 2015; 31(3):233-9.

13. Maslova OO, Shuvalova NS, Sukhorada OM, Zhukova SM, Deryabina OG, Makarenko MV, Govseiev DO, Kordium VA. Heterogeneity of umbilical cords as a source for mesenchymal stem cells. Dataset Papers in Biology 2013; 2013: Article ID 370103.

14. Théry M, Bornens M. Cell shape and cell division. Curr Opin Cell Biol. 2006;18(6):648-57.

15. Wagner W, Horn P, Castoldi M, Diehlmann A, Bork S, Saffrich R, Benes V, Blake J, Pfister S, Eckstein V, Ho AD. Replicative senescence of mesenchymal stem cells: a continuous and organized process. PLoS One. 2008;3(5):e2213.

16. Fehrer C, Brunauer R, Laschober $G$, Unterluggauer $H$, Reitinger $S$, Kloss $F$, Gülly C, Gassner R, Lepperdinger G. Reduced oxygen tension attenuates differentiation capacity of human mesenchymal stem cells and prolongs their lifespan. Aging Cell. 2007;6(6):745-57.

17. Suzuki K, Takahashi K. Reduced cell adhesion during mitosis by threonine phosphorylation of beta1 integrin. $J$ Cell Physiol. 2003;197(2):297-305.

18. Lancaster OM, Le Berre M, Dimitracopoulos A, Bonazzi D, Zlotek-Zlotkiewicz E, Picone R, Duke T, Piel M, Baum B. Mitotic rounding alters cell geometry to ensure efficient bipolar spindle formation. Dev Cell. 2013;25(3):270-83.

19. Sit KH, Bay BH, Wong KP. Reduced surface area in mitotic rounding of human Chang liver cells. Anat Rec. 1993;235(2):183-90. 
20. Loetscher PD, Rossaint J, Rossaint R, Weis J, Fries M, Fahlenkamp A, Ryang YM, Grottke O, Coburn M. Argon: neuroprotection in in vitro models of cerebral ischemia and traumatic brain injury. Crit Care. 2009;13(6):R206.

21. Fahlenkamp AV, Rossaint R, Haase H, Al Kassam H, Ryang $Y M$, Beyer $C$, Coburn $M$. The noble gas argon modifies extracellular signal-regulated kinase $1 / 2$ signaling in neurons and glial cells. Eur J Pharmacol. 2012;674(2-3):104-11.

Ростові показники культур МСК Вартонова студня, отримані методом збереження клітин зі зниженим рівнем адгезії, при культивуванні в різних газових сумішах

Н. С. Шувалова, В. А. Кордюм

Мета. Оцінити проліферацію в культурах мезенхімальних стовбурових клітин Вартонового студню людини (МСК-ВС), отриманих за допомогою збереження клітин, що спонтанно відкріпились, в різних газових сумішах, що містять фізіологічні концентрації кисню. Методи. Починаючи з першого пасажу, МСКВС культивували протягом 4 пасажів («головна» лінія). На кожному пасажі після 7 днів кількість клітин підраховували. На 0, 1 i 2 пасажі, на 3 добу культивування, кондиціоноване середовище збирали і переносили на інший флакон. Отримані таким чином адгезивні клітини культивували до набуття достатніх розмірів і конфлюентності (70-80 \%), після чого пасували за допомогою розчин трипсину та ЕДТА («побічні» лініі), підраховуючи кількість на кожному пасажі. Крім стандартних умов $\mathrm{CO}_{2}$-інкубатора, аналогічне культивування проводили в газових сумішах: на основі азоту (3 \% кисню, $4 \% \mathrm{CO}_{2}, 93 \%$ азоту) і аргону (3\% кисню, 4 \% $\mathrm{CO}_{2}, 93$ \% аргону). Результати.Рівень проліферації в «побічних» лініях, отриманих з культур на 0 і 1 пасажі, практично співпадав 3 таким для «основної» лінії. Ми спостерігали зниження рівня мультиплікації в «побічних» лініях, подібне до такого в «головній». Для культур, що походять 3 клонів, отриманих 32 пасажу, рівень проліферації був достовірно нижчим. Культивування в газових сумішах, що містили $3 \% \mathrm{O}_{2}$ мало стимулюючий вплив на рівень проліферації. Цей ефект був більш вираженим в суміші на основі аргону. Висновки. Культивування МСК-ВС в газових сумішах, що містили фізіологічні концентрації кисню, дозволило оптимізувати запропонований метод збереження клітин, що спонтанно відкріпились від субстрату.

Кл юч о в і с с о в а: мезенхімальні стовбурові клітини, проліферація, субпопуляція, фізіологічні концентрації кисню
Ростовые показатели культур МСК-ВС, полученных методом сохранения клеток с пониженной степенью адгезии, при культивировании в различных газовых смесях

Н. С. Шувалова, В. А. Кордюм

Цель. Оценить пролиферацию в культурах мезенхимальных стволовых клеток Вартонового студня человека (МСКBC), полученных с помощью метода сохранения спонтаннооткрепившихся клеток, в различных газовых смесях, содержащих физиологические концентрации кислорода. Методы. Начиная с первого пассажа, МСК-ВС культивировали в течение 4 пассажей ("основная" линия). На каждом пассаже после 7 дней количество клеток подсчитывали. На 0, 1 и 2 пассаже, на 3 сутки культивирования, кондиционированную среду собирали и переносили на другой флакон. Полученные таким образом адгезивные клетки культивировали до приобретения достаточных размеров и конфлюентности (70-80 \%), после чего пассировали с помощью раствора трипсина и ЭДТА ("побочные" линии), подсчитывая количество на каждом пассаже. Кроме общепринятых условий $\mathrm{CO}_{2}-$ инкубатора, аналогичное культивирование проводили в газовых смесях на основе азота (3 \% кислорода, 4 \% $\mathrm{CO}_{2}, 93 \%$ азота) и аргона (3\% кислорода, $4 \% \mathrm{CO}_{2}, 93 \%$ аргона). Результаты. Уровень пролиферации в «побочных» линиях, полученных из культур на 0 и 1 пассаже, практически совпадал с таковым для "основной" линии. Мы наблюдали снижение уровня мультипликации в "побочных" линиях, соответствующий такому "основной". Для культур, происходящих из клонов, полученных на 2 пассаже, уровень пролиферации был достоверно ниже. Культивирование в газовых смесях, содержащих 3 \% $\mathrm{O}_{2}$ имело стимулирующее влияние на уровень пролиферации. Этот эффект был более выраженным в смеси на основе аргона. Выводы. Культивирование МСК-ВС в газовых смесях, содержащих физиологические концентрации кислорода, позволило оптимизировать предложенный метод сохранения клеток, спонтанно открепились от субстрата.

Ключевы е сл ова: мезенхимальные стволовые клетки, пролиферацияб субпопуляция, физиологические концентрации кислорода

Received 05.09.2015 